\title{
A REVIEW OF EUROPE'S TRANSITION FROM FOSSIL FUELS TO RENEWABLE ENERGY USING CIRCULAR ECONOMY PRINCIPLES
}

\author{
Nicolae Pintilie \\ Bucharest University of Economic Studies, Bucharest, Romania \\ pintilienicolae15@stud.ase.ro
}

\begin{abstract}
More and more public and private organizations are trying to integrate the concept of circular economy into their daily operations. Given the existing pressures related to climate change, there are various debates in the literature on how to reduce the impact, and one of these debates is the use of renewable energy to the detriment of fossil fuels. This paper aims to create an image of the link between circular economy and the transition from fossil fuels to renewable energy through specialized papers published between 2000 and 2020 and through statistics published by International Agencies such as Eurostat. In this way, this paper is based on the study and analysis of the updated databases regarding the mentioned indicators. Moreover, the paper also discusses different possibilities of circular economy use and how they can be integrated into the European body, with a positive effect on the society and environment. The study found that European Union energy supply is increasingly based on renewable resources, the use of fossil fuels being limited from one year to another. At the same time, even if in the last decades the European Union has been characterized by industrialization and urbanization, there can be seen a growing efficiency of the energy system in the conditions in which the GDP per capita had a fulminant growth of over $50 \%$. Moving forward, one of the most interesting result of the paper is related to a massive concentration of works in the last two years of the period considered in the analysis. In other words, there is a great opportunity for more scientific research in the field. Despite this, researchers agree that the principles of the circular economy contribute to the conversion of the energy system, with positive effects on society, ensuring sustainability, productivity and efficient waste management. At the end, in order to support the energy transition, a number of institutions such as the European Investment Bank are supporting initiatives that aim to invest in objectives such as new technologies which could adopt circular economy. The paper also presents possible limits of the research, but also future directions of its development.
\end{abstract}

Keywords: Renewable energy, circular economy, fossil fuels, sustainability, environment, energy transition DOI: https://doi.org/10.24818/beman/2021.11.2-07

\section{INTRODUCTION}

Following the 2019 Climate Action Summit in New York under the auspices of the United Nations, it was set to reduce greenhouse gas emissions by $45 \%$ over the next 10 years and zero emissions by 2050 . The effect of greenhouse gases has been easily seen in various parts of the world (rising sea levels, 
deforestation, high temperatures), so governments have been trying for years to find ways to reduce climate change.

The possible solutions related to all these problems concern the notion of sustainability, seen through three dimensions: infrastructure, agriculture, renewable energy. Given the population growth in urban areas, but also the process of industrialization, energy demand is constantly growing. Economists, researchers, policy makers are focusing on the relationships energy creates with economic development and economic growth. Along time, the interdependence between energy consumption and economic growth governed the scientific research around the world, generating strong debates (Cicea et al., 2021). The transition from fossil fuels to renewable energy is a natural process given climate change. The energy transition is defined as a long process in which traditional fuels are replaced by green energy produced from renewable sources (Smil, 2016; Mutezo \& Mulopo, 2021).

The review paper's primary objective is to provide perspectives on Europe's energy transition in relation to circular economy. Moreover, based on existing literature, the analysis is trying to see if the circular economy can be considered a part of the change.

The subject is a major one at the international level, considering the fact that more and more organizations assume targets for certain periods of time regarding the protection of the environment and the reduction of the carbon footprint.

\section{LITERATURE REVIEW}

Until now, no common denominator has been reached regarding the definition of the concept of circular economy. In general, the circular economy means keeping resources in a usable state as much as possible before they are disposed of as waste (Mutezo \& Mulopo, 2021). The circular economy reduces the quantities of raw materials, thus reducing the effects on the environment.

The concept was popularized by David Pearce in 1990, but the biggest literature boom took place in the early 2000s (Stahel, 1982). Since then, the whole concept evolved and in the current times it is associated with innovation (procedural and technical), and new business models: a new way of production (Veleva \& Bodkin, 2018), and of consumption, when being understood in relation to renewable energy (Pintilie, 2021), and even with economic growth and intellectual capital (Nedelea et al., 2018; Vuţă et al. 2018).

One of the most used definition for circular economy is that "emphasizes product, component and material re-use, re-manufacturing, refurbishment, repair, cascading and upgrading as well as solar, wind biomass and waste-derived energy utilization throughout the product value chain and cradle-to-cradle life cycle" (Korhonen et al., 2018).

Over time, the concept of circular economy has tried to be implemented in various sectors of activity: 


\section{a) Circular economy and manufacturing}

Manavalan and Jayakrishna (2019) conducted an analysis of the concept in the field of supply chain of manufacturing companies. The authors found that there is a great symbiosis between the supply chain and the circular economy by the fact that high benefits are obtained in terms of resources and energy consumption. The study examined a paper manufacturing company in Southern India and the findings showed that the company produced auxiliary resources that could be used in other industries: the bagasse residue could be supplied to spirit producers operating in close proximity, the steam harvested from boiling pulp could be used to generate electricity for the operations instead of using coal, or reduce the coal consumption, the fly ash by-product could be sold to nearby cement producers. Using technology, manufacturers are informed of how much waste and where they are experiencing losses within the value chain, thus improving overall efficiency and redirecting waste usage.

b) Circular economy and Supply Chain Management

In order to create added value and to adopt less costly decisions for the environment and society, the specialists agreed that the principles of the circular economy must be included in the companies' operations (Geissdoerfer et al., 2018). Schroeder et al. (2018) analysed circular economy in relation with Global Value Chains: the concept was analysed for both multi-nationals and small and medium organisations, specifically in low-income countries. Following the study, the authors found that developed countries use less of the notion of circularity than low-income countries, but the question is how lowincome countries can act in a more sustainable way, taking into account that "use-and-dispose" narrative which characterize the current global value chains has a negative impact on low-income countries? Technology can be the key to success in this operation, because there are the proper means to create the value add within the value chain through robotics.

c) Circular Economy and Biogas for Electrification

In the literature, the relationship between biogas and circular economy has been presented as one evolving along time. For instance, as suggested by Cicea et al. (2019), the scientific research moved from relating biogas production and sustainability in the past to biogas and circular economy in the present. In the same time, this relationship has been detailed in China and Ireland (Mutezo \& Mulopo, 2021), where the development of rural biogas programs, led to multiple benefits (economic, social, environmental). According to Xu et al., (2018), in China, recently, one of the largest carbon emitters is livestock waste, and farmers have focused on circular activities, both in agricultural activities and in waste management. Biogas production from waste, organic fertilizers and electricity generation are the effects of China's recycling programs.

On the other hand, Blades et al. (2017) studied the application of circular economy in Northern Ireland, focusing on anaerobic digestion technology to generate electricity. As in many other parts of the world, 
Pintilie, $\mathbf{N}$.

agriculture in the region where the study was conducted is one of the most important activity sector, and it is also the largest greenhouse gas emitter. In order to reduce the dependence of fossil fuels, authorities have tried to stimulate local biogas initiatives. There were more than 90 applications for digestion plants since 2013, the majority of them with the porpose of electricity generation, but there were also applications for heat production. The authors also concluded that the anaerobic digestion technology could be the centre of "Smart Rural Energy Infrastructure", taking into account that the raw material is very easily to procure in the rural farming communities (even if we talk about livestock or local food waste) (Blades et al., 2017).

d) Circular Economy and Waste Management

Food waste is considered by many specialists an important cause of negative effects on the environment. Principato et al. (2019) has led research on the transition to the circular economy in the pasta production field in Italy in order to improve waste management. The authors identified the fact that material losses had significant quantities in the first phases of the supply chain (from agriculture to industrial processing) and in the final phases (sale and consumption). According to Principato et al. (2019), in the case of pasta producer from Italy, $23 \%$ of the wastage occurred between the cultivation and consumption phases. Given these aspects, by adopting the circular economy, the waste resulting from the cultivation process can be used as feed, and the waste from the consumption phase can be donated to food banks.

The circular economy aims at the collective construction of sustainable balances, so that everyone must adopt solutions depending on the existing resources in a certain space and the energy needs. In this sense, the maximum cooperation of all the organisms in a territory is necessary, but not sufficient (Mutezo \& Mulopo, 2021).

Besides cooperation, another concept closely related to the circular economy is the efficient use of resources. It is important that the resources are distributed efficiently, depending on the recognition of the maximum field of use, so that through the approaches of creative transformation the circular economy is reached.

Going further, the circular economy achieves the following strategic milestones: reducing the consumption of primary resources, intensifying research and development, creating new jobs and proper waste management. In addition, this new economic model (as it is also called) creates a connection between sustainability and economic well-being (Drăgoi et al., 2018). Moreover, circular economy is a key concept in the process of energy transition: on one hand, Chen \& Kim (2019) stated that both concepts share common characteristics, and the most important is the trying to achieve sustainable goals; on the other hand, Kalcenko et al. (2019) stated that if we want a low carbon future, than we should act according to circular economy principles. 


\section{ENERGY SUPPLY AND DEMAND TRENDS}

According to International Energy Agency (2020), the European Union is the world's second largest economy in nominal terms after the United States of America. In 2019, the EU's gross domestic product (GDP) represented one-quarter of the global economy, amounted over EUR 16.4 trillion. Going further with the statistical data, the share of the population of the European Union compaing with the global scale is $6.9 \%$, the share of energy consumption at the global scale is $12 \%$, and the share of carbon dioxide emissions also at the global scale is $9 \%$.

The population of the European Union increased by 7\% between 1990 and 2017, while the Gross Domestic Product per capita increased by $50 \%$. From the point of view of environmental protection, between the same years, the European Union was concerned with finding alternative methods of providing the necessary energy, with low impact on the environment, so that energy-related greenhouse gas emissions decreased by $20 \%$.

Regarding the sources of energy production, they are diversified at the level of the European Union, the energy being ensured both from the burning of fossil fuels, and from renewable and nuclear sources. In fact. at the level of 2017, the total energy production was ensured from the following sources:

- Fossil fuels $-41 \%$;

- Nuclear $-29 \%$;

- Bioenergy and waste $-20 \%$;

- Other renewables $-10 \%$.

Index 1990=1

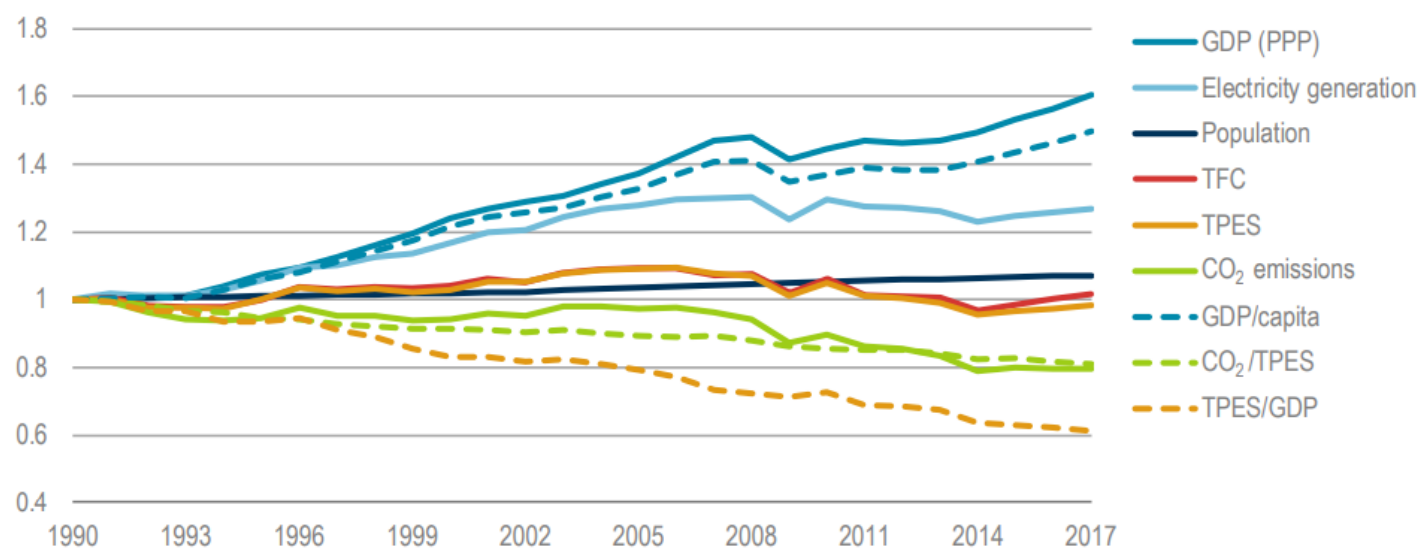

FIGURE 1. ENERGY RELATED CO2 EMISSIONS AND MAIN DRIVERS (1990 - 2017)

Source: International Energy Agency (2020)

GDP (PPP) $=$ Gross Domestic Product (Purchasing Power Parity);

TFC = Total Final Consumption;

TPES = Total Primary Energy Supply; 
Pintilie, N.

The European Union has been concerned about reducing the carbon footprint of the environment, so there is a decrease in energy intensity in the economy, but also a decrease in emissions from energy production. These things explain the 50\% increase in the Gross Domestic Product per capita and a $20 \%$ decrease in greenhouse gas emissions.

In fact, even between 2017 and 2019, energy produced from renewable sources in all electricity increased from $215,730,912$ to $229,669,385$ (6.4\%), which once again shows the European Union's concern regarding the friendly energy transition with the environment.

TABLE 1. TOTAL ENERGY SUPPLY BY PRODUCT

\begin{tabular}{|c|c|c|c|c|}
\hline Indicator & 2017 & 2018 & 2019 & $\begin{array}{l}2019 \text { vs } \\
2010 \\
\text { Deviation }\end{array}$ \\
\hline Solid fossil fuels & 218,813 & 210,465 & 169,041 & $-23 \%$ \\
\hline Peat and peat products & 2,177 & 2.364 & 2,304 & $6 \%$ \\
\hline Oil shale and oil sands & 4,202 & 4,542 & 2,955 & $-30 \%$ \\
\hline Natural gas & 33,855 & 324,820 & 335,718 & $1 \%$ \\
\hline $\begin{array}{l}\text { Oil and petroleum products (excluding } \\
\text { biofuel portion) }\end{array}$ & 470,946 & 462,956 & 460,489 & $-2 \%$ \\
\hline Renewables and biofuels & 215,731 & 222,477 & 229,669 & $6 \%$ \\
\hline Non-renewable waste & 13,541 & 13,610 & 13,901 & $3 \%$ \\
\hline Electricity & -393 & 761 & 253 & $-164 \%$ \\
\hline Heat & 1,133 & 1,080 & 1,091 & $-4 \%$ \\
\hline Nuclear heat & 195,602 & 195,738 & 196,928 & $1 \%$ \\
\hline
\end{tabular}

Source: author based on Eurostat (2020)

Reducing the use of fossil fuels to produce electricity is not a temporary phenomenon, this is visible since 1 decade ago. If we take into account the period 2010 - 2019, solid fossil fuels and peat and peat production felt by $31 \%$, while oil and petrolium products (+ oil shale and oil sands) dropped by nearly 32 $\%$.

Nuclear energy production has also been declining, with an $11 \%$ drop in a decade. Renewable energy production is increasing year by year and the main causes are bioenergy, and also electricity from wind and solar sources. 
Pintilie, N.

A REVIEW OF EUROPE'S TRANSITION FROM FOSSIL FUELS TO RENEWABLE ENERGY USING CIRCULAR ECONOMY PRINCIPLES

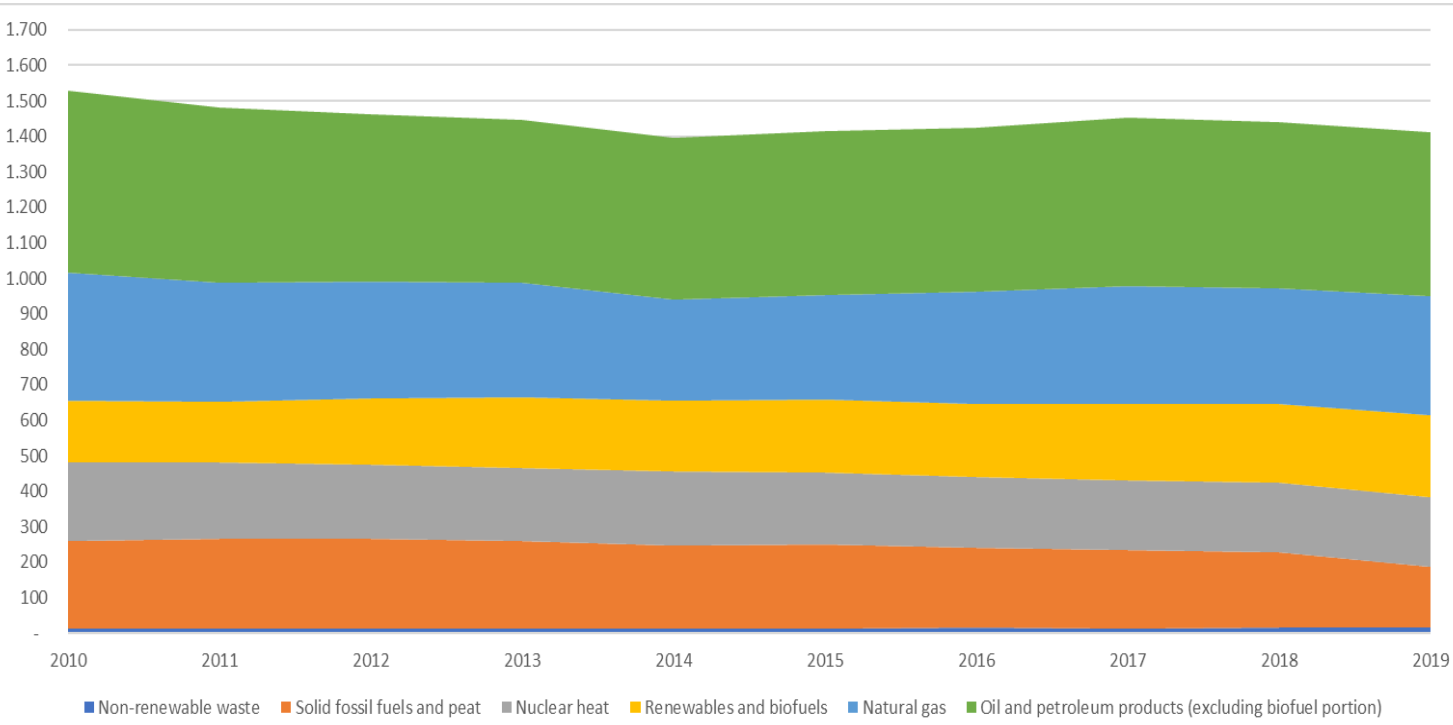

FIGURE 2. TOTAL ENERGY SUPPLY BY PRODUCT

Source: Eurostat

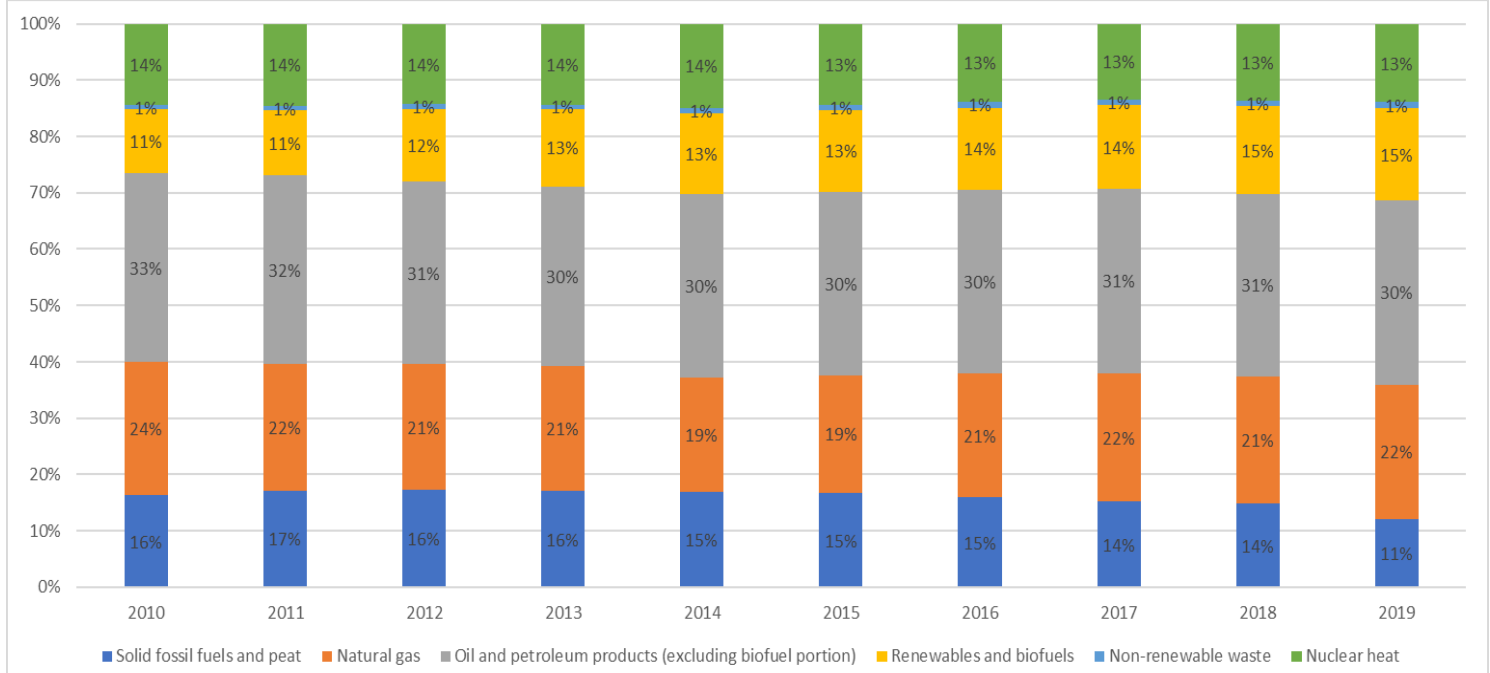

FIGURE 3. SHARE OF TOTAL ENERGY SUPPLY BY PRODUCT

Source: author, using Eurostat

As it is shown in Figure 3, the only product which has a greater share of total energy supply comparing 2019 with 2010 is represented by Renewables and Biofuels. On the other hand, it is evident that at the level of European Union the oil \& petrolium and natural gas are very important at the moment, with a big amount in total energy supply. This observation can show us that the conversion of the fossil fuels to 
Pintilie, N.

renewable energy is on the way, we are at the beginning taking into account the time scale so there is a lot of room from investors and authorities to bring about tremendous improvements in the field.

\section{TRANSITION FROM FOSSIL FUELS TO RENEWABLE ENERGY THROUGH INVESTMENTS}

At the level of the European Union, every year over 2.3 billion tons of wishes are produced, both from the activity of individuals and from the activity of legal entities. Also, on average, each individual in the European Union annually produces half a ton of household waste, of which less than half is recycled. All this waste makes its mark on the environment, while requiring costs for their management. In this way, the circular economy comes as a solution to all these problems, questioning principles such as redesign, rethinking, repositioning business processes, materials used.

Thus, if in the previous chapter the transition of the energy system of the European Union was analyzed from a statistical point of view, in this chapter the research will be focused on the investments that the European Investment Bank has made lately in order to facilitate the transition of EU countries to the circular economy. According to European Investment Bank Group (2021), between 2016 and 2020 the bank provided more than $€ 2.7$ billion in order to co-finance circular economy projects in different sectors. In addition, The European Investment Bank also provided financial an technical advisory support in order to improve the bankability of circular economy projects, not only the capital.

According to scientists, it is proven that the transition from the traditional economy to the circular economy ensures the conservation of resources, increasing competitiveness, creating new jobs, thus reducing the pressure of anthropogenic activities on the environment (Ellen MacArthur Foundation, 2019) and raising awareness on environment protection as a consequence of economic development (Pintilie et al., 2020). Moreover, the circular economy is closely linked to technological innovation; thus, it is possible to reach an increase in resource productivity by up to 3\% (McKinsey\&Company, 2016). Going further, the European Commission (2014) estimated that the transition of EU countries to the circular economy would create more than 2 million new jobs by 2030, reducing dependence on certain imported raw materials (European Investment Bank, 2021). Finally, through the transition to the circular economy, business models change by the fact that production processes are updated to new standards, which leads to reductions in materials, energy, and ultimately costs (European Investment Bank, 2021).

In the period 2016-2020, the European Investment Bank financed projects related to the circular economy in various fields: urban development and energy, mobility, waste management, water reserves management, industry and services, agriculture and bioeconomy 
Pintilie, N.

A REVIEW OF EUROPE'S TRANSITION FROM FOSSIL FUELS TO RENEWABLE ENERGY USING CIRCULAR ECONOMY PRINCIPLES

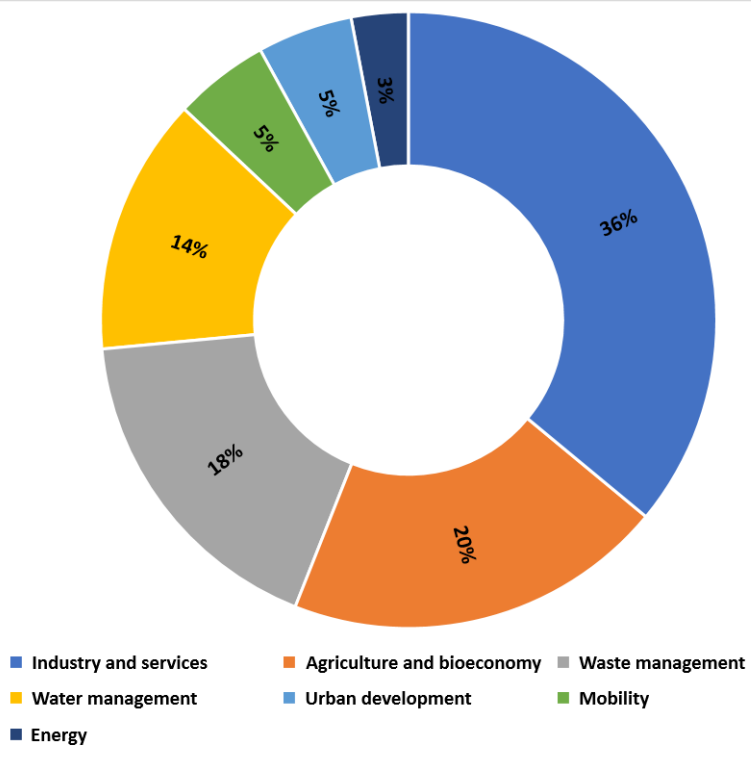

FIGURE 4. SHARE OF INVESTMENT IN CIRCULAR ECONOMY PROJECTS

Source: author, based on European Investment Bank (2021)

In Table 2 it is very easu to observe several circular economy projects which received finance from European Investment Bank:

TABLE 2. FINANCED CIRCULAR ECONOMY PROJECTS BY EUROPEAN INVESTMENT BANK

\begin{tabular}{|c|c|c|c|c|}
\hline $\begin{array}{l}\mathrm{Nr} . \\
\mathrm{Crt}\end{array}$ & $\begin{array}{l}\text { Company } \\
\text { name }\end{array}$ & $\begin{array}{l}\text { Loan } \\
\text { value (€ } \\
\text { million) }\end{array}$ & Country(es) & Short description \\
\hline 1 & $\begin{array}{l}\text { De Lage } \\
\text { Landen } \\
\text { (DLL) }\end{array}$ & 100 & $\begin{array}{l}\text { Belgium and } \\
\text { Netherlands }\end{array}$ & $\begin{array}{l}\text { DLL is responsible for refurbishing and leasing used equipments to } \\
\text { companies. The goal of the loan is to bring cost savings to SME's, } \\
\text { and allow them to invest in other areas, making a great contribution } \\
\text { to circular economy targets. }\end{array}$ \\
\hline 2 & $\begin{array}{l}\text { Ecotitanium } \\
\text { Plant }\end{array}$ & 30 & France & $\begin{array}{l}\text { This loan envisages the construction of the first European factory } \\
\text { to melt titanium from aircraft waste, which contributes to reducing } \\
\text { import dependence. At the same time, it ensures the reduction of } \\
\text { up to } 100,000 \text { tons of CO2 per year, resulting from the processing } \\
\text { of this metal. Moreover, through this investment, new jobs are } \\
\text { created, ensuring the increase of the qualification in the } \\
\text { metallurgical field of the population in the area. }\end{array}$ \\
\hline 3 & Ultimaker & 15 & Netherlands & $\begin{array}{l}\text { This investment envisages the development of 3D printers that use } \\
\text { plastic waste to produce new items. The loan also aims to } \\
\text { strengthen the research and development process. }\end{array}$ \\
\hline
\end{tabular}


Pintilie, N.

A REVIEW OF EUROPE'S TRANSITION FROM FOSSIL FUELS TO RENEWABLE ENERGY USING CIRCULAR ECONOMY PRINCIPLES

\begin{tabular}{|l|l|l|l|l|}
\hline 4 & $\begin{array}{l}\text { Belfius Smart } \\
\text { Cities, } \\
\text { Climate and } \\
\text { Circular } \\
\text { Economy }\end{array}$ & Belgium & $\begin{array}{l}\text { This loan aims to encourage private investment in order to improve } \\
\text { energy efficiency. The loan also supports local government } \\
\text { initiatives related to sustainability projects in the fields of education } \\
\text { and health. }\end{array}$ \\
\hline 5 & $\begin{array}{l}\text { Novamont } \\
\text { Renewable } \\
\text { Chemistry }\end{array}$ & 30 & Italy & $\begin{array}{l}\text { This company deals with the development of biodegradable plastic } \\
\text { based on renewable resources }\end{array}$ \\
\hline 6 & $\begin{array}{l}\text { Winnow } \\
\text { ande }\end{array}$ & 7.5 & Romania & $\begin{array}{l}\text { Winnow is a company which deals with food waste. The loan is } \\
\text { destined to developing software and hardware solutions in order to } \\
\text { track the amounts and types of food waste. The final objective of } \\
\text { the company is to prevent food waste by providing accurate data to } \\
\text { users. }\end{array}$ \\
\hline 7 & Orbital & 15 & Sweden & $\begin{array}{l}\text { Orbital developed a water recycling technology which can save up } \\
\text { to 90 \% of the water and 80 \% of the energy used, compared with } \\
\text { a conventional shower. The loan is destined to expand the know- } \\
\text { how and to build the products in order to be able on the markets. }\end{array}$ \\
\hline
\end{tabular}

Source: author, based on European Investment Bank (2021)

\section{RENEWABLE ENERGY AND THE CIRCULAR ECONOMY IN THE LITERATURE}

The last step in highlighting the transition from fossil fuels to renewable energy through the circular economy is to analyze the literature, with reference to the European Union. In this way, Web of Science database was choasen, in order to see the scientific papers that contain the terms involved. Web of Science database was chosen for two reasons: the exhaustiveness of the data set and the compatibility with the analysis.

In this way, 28 records weere identified which matched the analyzed topic. Only English language was taking into account, and the analysis interval was $2000-2020$. 


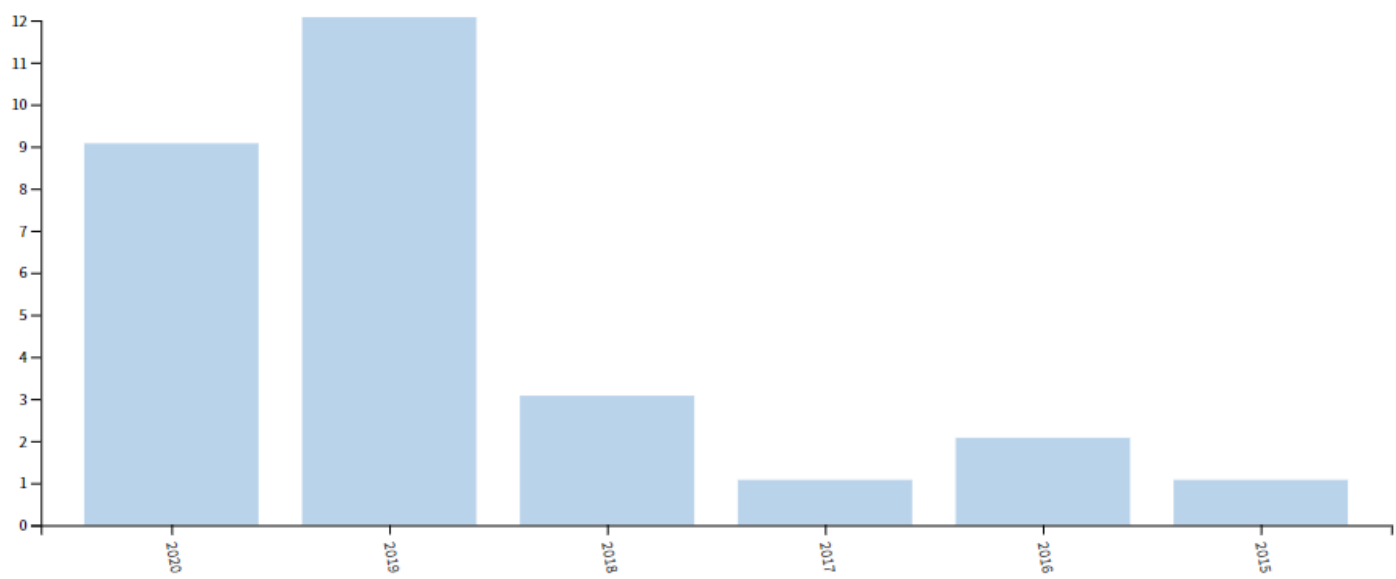

FIGURE 5. TIMELINE OF THE SCIENTIFIC PRODUCTION

Source: author, using WoS database

Despite the fact the the analysis was conducted taking into account the documents between 2000 and 2020, we found out that database containing the mentioned key words have publications starting with 2015. This first analyse shows us that the transition to renewable energy through circular economy principles is just at the beginning. Since 2015 till 2020, the number of papers included in the main flow of publications grew semnificatively, showing the growing interest for the concerned theme. What is more, the last two years of the analysed period account for almost $75 \%$ of the total number of the articles considered in this study.

In this way, in addition to the statistical indicators reported by international sites, it is observed that scientific publications have been following this topic lately, which contributes to the increase of knowledge in the field of circular economy. This new type of economy changes traditional customs and limits the use of fossil fuels to produce energy, thus ensuring humanity's transition to green, environmentally friendly energy.

\section{CONCLUSIONS}

Globally, all organisms talk about the transition from fossil fuels to green energy. Within this paper, the research revelead that the EU's economy is expected to continue growing and taking into account the climate changes it is a very known need to make the transition to renewable energy. Economic development is very well linked to energy supply. Even if the energy demand dropped from one period to another, it is imperative to ensure the transition to green energy in order to grow the share of renewable energy in total energy supply. From this point of view, circular economy principles come to our aid. 
As anyone can observe in the paper, there has been a growing attention to renewable resources. Table 1 and also Figure 2 show that at the level of European Union there are changes regarding the structure of total energy supply, with a growing attention to renewables and biofuels.

Moving forward, all the datasets are sustained by several projects financed by European Investment Bank through which the principles of the circular economy are introduced in daily activities, and thus in energy needs. In addition, it is evident from Table 2 that the circular economy principles are implemented throughout the Europe, so there are no disadvantaged countries, all member states want to contribute to the EU's environmental targets.

To make matters better, over the past years $(2015-2020)$, there has been a growing interest from the authors regarding the subject, deliberating the concepts from many angles.

Even though the author explained the concepts used within this paper, the study has some limitations.

First of all, the goal of the paper was a descriptive one. So, taking into account datas the analysis tried to make some correlations, but there are not sustained by an econometric model. For this reason, a future research may take into consideration to create an econometric model in order to analyze the key concepts from a quantitative point of view. Moreover, only WoS database was used in order to obtain articles. A similar analysis could be conducted using other databases, such as Scopus, which may influence the number of selected articles and provide other query options.

\section{REFERENCES}

Blades, L., Morgan, K., Douglas, R., Glover, S., De Rosa, M., \& Cromie, T. (2017). Circular biogasbased economy in a rural agricultural setting. Energy Procedia. 123: 89 - 96.

Chen, W.-M., \& Kim, H. (2019). Circular economy and energy transition: a nexus focusing on the nonenergy use of fuels. Energy \& Environment. 30(4): 586 - 600.

Cicea, C., Marinescu, C., \& Pintilie, N. (2019). Biogas-innovation map: revealing links and dynamics in the field, Proceedings of the 13th International Management Conference: Management strategies for high performance,1st-2nd November, Bucharest, Romania, pp. 483-492.

Cicea, C., Ciocoiu, C. N., \& Marinescu, C. (2021). Exploring the Research Regarding Energy-Economic Growth Relationship. Energies, 14(9), 2661. https://doi.org/10.3390/en14092661

Drăgoi, M.C., Popescu, M.F., Andrei, J.V., \& Mieilă, M. (2018). Developments of the circular economy in romania under the new sustainability paradigm. Economic Computation \& Economic Cybernetics Studies \& Research, 52(2). https://doi.org/110.24818/18423264/52.2.18.08

Ellen MacArthur Foundation. (2019). The virtuous circle. Ellen MacArthur Foundation. doi:10.2867/016569

Ellen MacArthur Foundation. (2019). The virtuous circle. Ellen MacArthur Foundation. Retrieved on 2nd of May, 2021, from https://library.oapen.org/handle/20.500.12657/47421

European Investment Bank. (2021). Circular Economy Overview 2021. Retrieved May 19, 2021, from https://www.eib.org/attachments/thematic/circular_economy_overview_2021_en.pdf 
Geissdoerfer, M., Morioka, S., de Carvalho, M., \& Evans, S. (208). Business models and supply chain for the circular economy. Jounal of Cleaner Production. 190: 712-721.

International Energy Agency. (2020). European Union 2020 - Energy Policy Review. Paris: IEA Publications.

Kalchenko, O., Evseeva, S., Evseeva, O., \& Plis, K. (2019). Circular economy for the energy transition in Saint Petersburg, Russia. E3S Web of Conferences. 110(9).

Korhonen, J., Honkasalo, A., \& Seppala, J. (2018). Circular economy: the concept and its limitations. Ecological Economics. 143: 37 - 46.

Manavalan, E., \& Jayakrishna, K. (2019). An Analysis on sustainable suppy chain for circular economy. Procedia Manufacturing. 33: 477 - 484.

McKinsey\&Company. (2016). The circular economy: Moving from theory to practice. Retrieved May 19, 2021,

https://www.mckinsey.com/ /media/McKinsey/Business\%20Functions/Sustainability/Our\%20Insight s/The $\% 20$ circular $\% 20$ economy $\% 20$ Moving $\% 20$ from $\% 20$ theory $\% 20$ to $\% 20$ practice/The $\% 20$ circular $\%$ 20 economy $\% 20$ Moving\%20from\%20theory\%20to\%20practice.ashx

Mutezo, G., \& Mulopo, J. (2021). A review of Africa's transition from fossil fuels to renewable energy using circular economy principles. Renewable and Sustainable Energy Reviews. 137.

Nedelea, A. M., Mironiuc, M., Huian, M. C., Bîrsan, M., \& Bedrule-Grigoruţă, M. V. (2018). Modeled interdependencies between intellectual capital, circular economy and economic growth in the context of bioeconomy. Amfiteatru Economic, 20(49): 616-630.

Pintilie, N., Cicea, C., \& Marinescu, C. (2020). A bibliometric study of environmental protection and economic development: revealing links and dynamics. Proceedings of the 14th International Management Conference: Managing Sustainable Organizations, 5th-6th November, Bucharest, Romania, pp. 335-345.

Pintilie, N. (2021). A bibliometric study of renewable energy and circular economy: revealing links and dynamics, Proceedings of the 36 th IBIMA Conference, Granada, Spain, ISBN 978-0-9998551-5-7

Principato, L., Ruini , L., Guidi, M., \& Secondi, L. (2019). Adopting the circular economy approach on food loss and waste: the case of italian pasta production. Resource, Conservation and Recycling. 144: 82 - 89.

Schroeder, P., Dewick, P., Kusi-Sarpong, S., \& Hofstetter, J. (2018). Circular economy and power relations in global value chains: tensions and trade-offs for lower income countries. Resource, Conservation and Recycling. 136.

Smil, V. (2016). Examining energy transition: a dozen insights based on performance. Energy Research and Social Science. 22: $194-197$.

Stahel, W. (1982). The business angle of circular economy - higher competitiveness, higher resource security and material efficiency. EMF volume.

Veleva, V., \& Bodkin, G. (2018). Corporate-entrepreneur collaborations to advance a circular economy. Journal of Cleaner Production, 20 - 37.

Vuţă, M., Vuţă, M., Enciu, A., \& Cioacă, S. I. (2018). Assessment of the circular economy's impact in the EU economic growth. Amfiteatru Economic, 20(48): 248-261.

Xu, X., Ma, Z., Chen, Y., Gu, X., Liu, Q., \& Wang, Y. (2018). Circular economy pattern of livestock manure management in Longyou, China. Journal of Material Cycles and Waste Management. 20(5): 1050-1062. 